\title{
Malign Priapism Secondary to Renal Cell Carcinoma Provoked Paraneoplastic Leukemoid Reaction: Report of The First Case
}

\section{Renal Hücreli Karsinomun İndüklediği Paraneoplastik Lökomoid Reaksiyona Sekonder Gelişen Malign Priapism: Bilinen İlk Olgu Sunumu}

\author{
Eşref Oğuz Güven, İsmail Selvi ${ }^{1}$, Mete Kilciler, Halil Başar \\ ${ }^{1}$ Dr. Abdurrahman Yurtaslan Ankara Ankara Oncology Training and Research Hospital, Department of Urology, \\ Ankara, TURKEY \\ ${ }^{2}$ Bahçeşehir University Faculty of Medicine, Department of Urology, İstanbul, TURKEY
}

Dergiye Ulaşma Tarihi: 26.02.2018 Dergiye Kabul Tarihi: 10.07.2018 Doi: 10.5505/aot.2018.64426

\section{ÖZET}

Malign priapism (MP), penis dokusunda tümöral invazyon veya metastaz sonucu oluşan priapism şeklidir. Paraneoplastik lökomoid reaksiyon (PLR)ise, çoğu solid tümörde gözlenebilen bir paraneoplastik sendrom tipi olup beyaz küre sayısının, lösemik tutulum olmaksızın 50x109/L üzerine çıktığı bir reaktif lökositoz tablosudur.Tüm priapism olgularının yaklaşık \%3-8'i malignite nedeniyle gelişmektedir. Primer olarak renal hücreli karsinomun (RHK) tetiklediği ve takipte tanıdan 4 y1l sonra gelişen akciğer metastazlarının da indüklediği PLR zemininde gelişen bir MP olgusu sunduk. Bilgilerimize göre, bu vaka literatürde bildirilmiş ilk olgusudur. Korpus kavernozuma herhangi bir tümöral infiltrasyon veya metastaz olmadığı halde, PLR'nin oluşturduğu hiperviskositeye bağlı intrakavernozal obstrüksiyonun yarattığı vasküler stazın, korporal drenajı engellediğini düşünmekteyiz. Olgumuzda görüldüğü gibi, PLR priapism ataklarına neden olabilmekte ve malignite varlığında başvuruya yol açan ilk belirti olabilmektedir.

Anahtar Kelimeler: Akciğer metastazı, Malign priapism, Paraneoplastik lökomoid reaksiyon, Renal hücreli karsinom

\begin{abstract}
Malign priapism (MP) is described due to tumoral invasion or metastasis to the penil corporeal tissue. Paraneoplastic leukemoid reaction (PLR) is reported in nearly all solid tumor types as a paraneoplastic syndrome. It is a reactive leukocytosis where white blood cell(WBC) count exceeds $50 \times 10^{9} / \mathrm{L}$ without evidence of leukemia. $3-8 \%$ of all priapism cases are caused by malignancy.We present a case of MP, showed up secondary to a PLR which was provoked firstly by the primary renal malignancy and it was again induced four years after by its lung metastasis. To our knowledge, this is the first case in the literature. We'd like to emphesize that there were no evidents of invasion or metastasis to corpus cavernosum. PLR can also give rise to priapism attacks and this may be the first symptom of a malignant condition.
\end{abstract}

Keywords: Lung metastasis, Malign priapism, Paraneoplastic leukemoid reaction, Renal cell carcinoma

\section{INTRODUCTION}

Priapism is a painful and abnormal erection, lasting more than four hours which occurs with or without sexual stimulation (1). Malign priapism (MP) has been described as priapism due to metastasis or invasion to the penis (2). Most of the metastatic lesions originate from the neighboring genitourinary and pelvic 
to range from $1 \%$ to $4 \%$ in small case series.LR has been reported in nearly all solid tumor types as a paraneoplastic syndrome and it is historically associated with poor outcomes (5).

We present a case of MP that showed up secondary to a LR which was provoked first by the primary renal malignancy itself and four years after by its lung metastasis. In the literature, only one bladder cancer case of MP which hyphotesised to occur as a consequence of intravascular obstruction due to blood hyperviscosity caused by Paraneoplastic LR(PLR), leading to a blood stasis in the cavernosa veins, and impeding the drainage of the corpora cavernosa was reported (6).

To our knowledge, this is the first case of PLR associated MP in a renal cell cancer patient which had occured as the first manifestion of the primary disease and its metastases four years after the successful radical therapy.

\section{CASE REPORT}

A 56 years old man admitted to emergency department with a complaint of spontaneously occured painful erection which was lasting for six hours. He denied any preceding intake of erection-enhancing medications or exposure to trauma, and was unaware of any systemic illness he might have had, with the exception of mild left flank pain and $37,5-39^{\circ} \mathrm{C}$ intermittant fever lasting for a month.In physical examination, penis was rigit, tender. Body temperature was $38,2^{\circ} \mathrm{C}$. Except leukocyte alkaline phospatase and WBC count which were $264 \mathrm{U} / \mathrm{L}$ and $74 \times 10^{9} \quad / \mathrm{L}$ respectively, laboratory tests were in normal ranges without any sign of obvious infection. Penile blood revealed hypoxia, hypercapnia, acidosis. Penile doppler ultrasound verified low flow priapism. Corporeal aspiration, irrigation and slow intracorporeal injection of epinephrine were performed and penil detumesence was achieved.

Sickling test was negative. Complete blood count revealed marked leukocytosis, hematologic malignancy was suspected and the patient was referred to an oncologist. Bone marrow aspiration showed the infiltration of increased mature neuthrophile infiltration. There was no sign of hematological malignancies. Further investigation with abdominal computerised tomography showed a mass measuring $10 \times 7 \times 5 \mathrm{~cm}$ in the left kidney. Magnetic resonance imaging(MRI) of lower abdomen and penis was clear. The situation was described as a paraneoplastic leukemoid reaction(PLR) provoked by the renal tumor.

Left radical nephrectomy was performed. Pathology reported Fuhrman grade3, pT3b renal cell carcinoma (Figure-1). In the early post operative period, WBC count sharply decresed to $27 \times 10^{9} / \mathrm{L}$ and fever attacs ceased. In the follow up period, he had not experienced any priapism attacks and WBC counts were in normal limits. Four years later, he had priapism attacks again with less severity. WBC count found to exceeded $50 \times 10^{9} / \mathrm{L}$. PET/FDG revealed two metastatic nodules, measuring 10 and $4 \mathrm{~mm}$ in the right lung inferior lobe superior segment (Figure-2). The patient refused metastasectomy and was referred to oncology department for further therapy. 


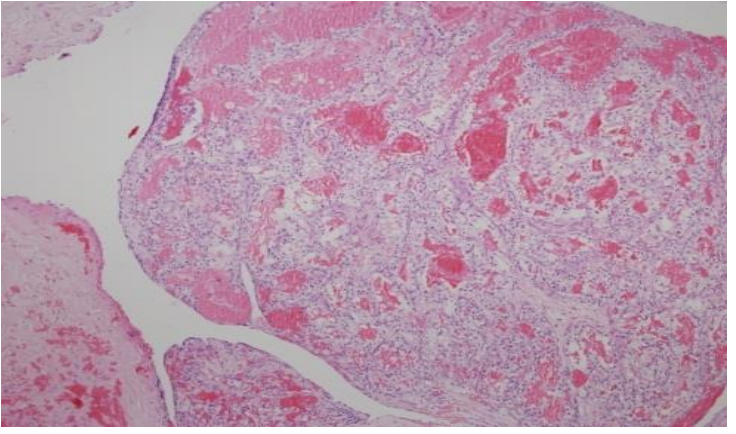

Figure 1. Image of Fuhrman grade-3, pT3b renal cell carcinoma with renal vein thrombosis $(\mathrm{x} 100$ magnification

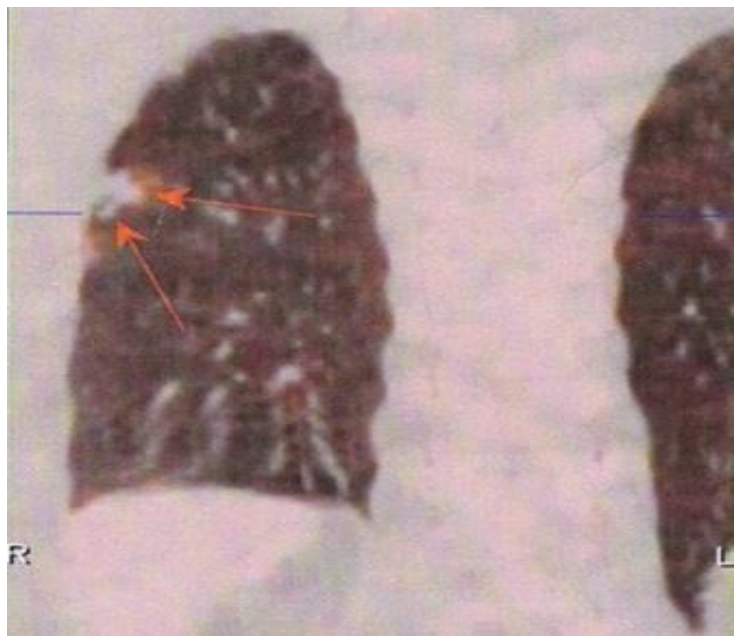

Figure 2. Image of lung metastasis in PET-CT

\section{DISCUSSION}

Priapism is an emergency condition characterized by full or partial penile erection that continues more than four hours beyond sexual stimulation and orgasm or is unrelated to sexual stimulation. Incidence of priapism in general population is 1.5 cases in every 100.000 people per year (2). There are two types of priapism: low flow (veno-occlusive or ischemic) priapism(LFP) and high flow (arterial or nonischemic) priapism. The most common cause of low flow priapism is idiopathic, while the cause of high flow priapism is mostly perineal or penile trauma. Other causes of ischemic priapism include hematological diseases such as sickle cell disease, hyperviscosity syndromes such as chronic myeloid leukemia, polycythemia vera, multiple myeloma and hypercoagulable state (7).

Penile metastasis is an extremely rare event which is usually a sign of disseminated disease. A review of 504 cases revealed that more than $69 \%$ of metastases are from bladder, prostate and rectosigmoid cancers. They were followed by kidney cancer with a ratio of $6.9 \%$. The retrograde venous route is considered the major pathway of tumor spread to the penis (3).

MP is a term firstly used by Peacock in 1938 to describe persistent, non-sexual erections caused by invasion of malignant cells into the cavernosal sinuses and their associated venous systems (2). As a symptom of penile metastases, MP frequency is reported from 20 to $53 \%$. MRI scanning is a reliable alternative for diagnosis and assessing the extend of the penile metastasis. Occlusion of the draining veins or secondary trombosis in the cavernosal spaces directly caused by metastatic tumor cells or hyperviscosity syndromes are the usual causes (3).

A PLR is defined as WBC count over $50 \times 10^{9} / \mathrm{L}$ associated with cancer but without evidences of leukemia or infection (4). LRs are attributed to the autoproduction of granulocyte colony stimulating factor and fever is an integral component of PLR (8). PLR is often associated with rapid tumor growth and poor clinical prognosis, although it resolves with the treatment of the underlying cancers (5).A review article covering 758 patients with solid tumours and leukocyte count over $50 \times 10^{9} / \mathrm{L}$; only 72 patients (10\%) was diagnosed as PLR. Rest of the patients were detected other disorders that could cause leukocytosis (9).

Two cases of LRs following sarcomatoid renal cell carcinoma without priapism was reported (10). But priapism following PLR without penil metastasis is a very rare entity. In literature, we can only find one priapism case following PLR that was provoked by bladder cancer (6). 
The mechanism of priapism in cases with leukemia is hypothesized to be due to hyperviscosity caused by hyperleukocytosis and aggregation of leukocytes inside the sinusoids of the corpora cavernosa resulting in sinusoidal engorgement and erection of the penis. Blockage of emissary veins and dorsal veins results in stoppage of the venous return (7).

In our case, a MP secondary to PLR leads to the diagnosis of renal cell carcinoma and its metastases. For two reasons, we believed that hyperviscosity caused by PLR was the cause of priapism. Firstly, MRI of lower abdomen and penis was completely normal both at the time of the primary tumor and four years after when the metastases were diagnosed. Secondly, priapism died out with the normalisation of the leukocyte counts and reappeared four years after with the second PLR attack caused by metatases of primary tumor. The progress of our case is consistent with the literature except that the patient has been alive for more than four years although in cases of MP and/or PLR, life expectancy is less than one year.

To our knowledge, this is the first case of a MP which occured secondary to a PLR provoked by the primary renal cell carcinoma itself and its lung metastasis which occured four years after a succesful radical surgery.

\section{CONCLUSION}

$3-8 \%$ of all priapism cases have been caused by malignant conditions. In these, the most frequent causes are genitourinary malignancies with demonstrable metastasis or invasions of the corpus cavernosum. On the other hand, PLR can rarely cause priapism without any demonstrable lesion in the corpus cavernosum.
We like to emphesize that there were no evidents of invasion or metastasis to corpus cavernosum. Although it is extremely rare, PLR can also give rise to priapism attacks and this may be the first symptom of malignancy, which is originated from genitourinary system.

\section{Conflict of interest: None}

\section{REFERENCES}

1. Rosenstein D, McAninch JW. Urologic emergencies. Med Clin North Am. 2004 Mar;88(2):495-518.

2. Liu S, Zeng F, Qi L et al. Malignant priapism secondary to isolated penile metastasis from a renal pelvic carcinoma. Can Urol Assoc J. 2014 Jul;8(7-8):E558-60. doi: 10.5489/cuaj.1695.

3. Mearini L, Colella R, Zucchi A, Nunzi E, Porrozzi C, Porena M. A review of penile metastasis. Oncol Rev. 2012 Jun 14;6(1):e10.

4. Shapiro DD, Potretzke A, Downs TM. Leukemoid reaction: a rare paraneoplastic syndrome in bladder cancer associated with a grave prognosis. Urology. $2014 \mathrm{Feb}$;83(2):2747.

5. Qing L, Xiang T, Guofu Z, Weiwei F. Leukemoid reaction in cervical cancer: a case report and review of the literature. BMC Cancer. 2014 Sep 15;14:670.

6. Rodríguez Alonso A, Romero Picos E, Suárez Pascual $G$ et al. Priapism following paraneoplastic leukemoid reaction in a patient with bladder cancer. Actas Urol Esp. 2004 JulAug;28(7):539-43.

7. Shaeer OK, Shaeer KZ, AbdelRahman IF, ElHaddad MS, Selim OM. Priapism as a result of chronic myeloid leukemia: case report, pathology, and review of the literature. J Sex Med. 2015 Mar;12(3):827-34.

8. Dukes JW, Tierney LM Jr. Paraneoplastic leukemoid reaction as marker for transitional cell carcinoma recurrence. Urology. 2009 Apr;73(4):928.e17-9.

9. Granger JM, Kontoyiannis DP. Etiology and outcome of extreme leukocytosis in 758 nonhematologic cancer patients: a retrospective, single-institution study. Cancer. 2009 Sep 1;115(17):3919-23.

10. Huang W, Wang F, Li Y, Duan F, Yu Z. Leukemoid reaction in sarcomatoid renal cell carcinoma: a two-case report. World J Surg Oncol. $2014 \quad$ Apr 19;12:100. 